\title{
REGION OF SOUTHERN AFRICA: INTERNATIONAL TRADE AND GLOBAL VALUE CHAINS
}

Ewa Cieślik, Ph.D.

Poznan University of Economics

Department of International Economics

Al. Niepodległości 10, 61-875 Poznań, Poland

e-mail: ewa.cieslik@ue.poznan.pl

Received 21 June 2014, Accepted 15 December 2014

\begin{abstract}
Integration of Southern Africa has resulted in changes in trade structures and production process across borders. The aim of this article is to present transformations taking place in the structure of trade exchange of the Southern African states (Botswana, Lesotho, Namibia, Swaziland, and South Africa) that are members of the Southern African Customs Union (SACU), and the position of South Africa in global value chains. South Africa seems to be the group of the most advanced countries in analyzed region. The analysis takes advantage of both the conventional methods of comprehensive study on international trade and the modern indicators and measures examining similarity, concentration or the position of South Africa in global value chains in general and sectoral terms.
\end{abstract}

Keywords: South Africa, SACU, international trade, global value chains.

JEL classification: F14, F15. 


\section{Introduction}

In the region of Southern Africa there are several grave barriers to regional cooperation, such as the disparities in the levels of social and economic development, the problem of poverty, institutional and infrastructural weakness, epidemics, political instability, and not infrequently military conflicts as well. Quite often, one of the reasons for the failure of integration were also attempts to transplant the integration solutions worked out in developed countries to Africa. These models, consistent with the literature on theories of international cooperation, did not perform well in the African reality. Despite the aforementioned barriers, however, the Southern African Customs Union (SACU) was established on 29 June 1910 and has remained in effect ever since, presently comprising five states, namely South Africa (SA) and the BLNS countries: Botswana, Lesotho, Namibia, and Swaziland. Boosting regional economic cooperation in Southern Africa is meant to promote the area's independence through gradual liberalisation of trade flows and in the future this arrangement could become a deeper type of integration, e.g. a common market.

The African continent is often analysed from the angle of poverty ${ }^{1}$, development assistance ${ }^{2}$, problems of the agricultural sector ${ }^{3}$, integration initiatives and relations ${ }^{4}$, political problems, national security, trade inequalities, or natural resources ${ }^{5}$. Only recently have publications showing Africa as an important growth pole and a potential partner in trade and foreign investments started to appear ${ }^{6}$. Therefore, the study represents a contribution to further deliberations on the changes of the position of Southern Africa in the global economy. The analysis presented below is aimed at characterising the transformations taking place in the structure of trade exchange of the SACU states and the position of SA in global value chains (GVCs). The analysis takes advantage of both the conventional methods of comprehensive study of foreign trade and the modern indicators and measures examining similarity, concentration or the position of a given country in global value chains. The analysis covers the years 2000-2012 (in some cases, also 2013), however, for the purpose of some selected issues (e.g. GVCs), the study period has been shortened due to the lack of relevant data. In order to ensure uniformity of its results, the study was based on data compiled by international organisations.

\section{Overview of the transformations in the trade policy in the region}

In the region of Southern Africa there is the oldest customs union in the world - SACU, initially designed to serve the economic and political interests of the British Empire ${ }^{7}$. The agreement established a customs territory with unified tariffs for third countries, allowed for 
unrestricted flow of goods within the union and introduced sharing profits between the members. It operated under these principles until $1969^{\circ}$, when a new SACU agreement was signed, on 11 December, with the aim to balance the union, as in fact its major beneficiary had been South Africa - the country that had been essentially determining the trade policy within the union . In the subsequent decades, SACU pursued the interests of the apartheid regime ${ }^{10}$. Only after the apartheid policy was abolished in 1994, there was an important renegotiation of customs agreements which led to the signing of the 2002 SACU Agreement, which eventually entered into force in 2004 and which introduced principles of a much more democratic nature to the union $^{11}$.

From that moment on, SACU, being an agreement solely between the countries of the Southern Africa region, has been pursuing exclusively the political and economic goals of its member states. It is worth pointing out that the new agreement has retained several issues from the 1969 agreement, e.g. the right of the members to introduce trade restrictions. Despite the fact that the other countries of the grouping have been attempting to make their SACU-related institutions independent from South African influences, they have not managed to fully do so. It should be noted that SACU is a typical example of the hub-and-spoke model ${ }^{12}$. In this case, South Africa is the hub, as the most developed country of the region (it generates almost $92 \%$ of the region's GDP), while the other members of the grouping are the 'spokes'. This is also the reason for the establishment, within SACU, of a system of compensations to the other members, intended to equalise the profits from the introduction of the customs union.

The introduction of the new SACU agreement resulted in the establishment of a number of bodies tasked with the implementation of the union's strategy. One of these is the SACU Council of Ministers, composed of representatives of all the members of the grouping, its task being to jointly work out a consensus regarding the SACU trade policy. The Chairperson of the SACU Council of Ministers changes on an annual basis. In 2012, the office was held by the representative of Botswana and in 2013, by the representative of Lesotho. Another body is the Tariff Board, tasked primarily with making recommendations regarding tariffs and retaliatory measures (anti-dumping, countervailing and safeguard duties) ${ }^{13}$. The new agreement has maintained the common import duty for third countries selling their goods in SACU markets and it has also retained the provisions concerning the sharing of profits from tariffs and excise duty. As a matter of fact, the privileged parties in this agreement are all the SACU members except for South Africa. While the latter generates around 98\% of the income from common tariffs, the BLNS receive in total around $55 \%$ of the funds from the common pool ${ }^{14}$. For instance, it has been estimated that in 2013-2014 the payment from the common pool of funds jointly collected from 
tariffs and excise duty will amount to around USD 725 billion, of which almost 500 billion will go to the four privileged countries ${ }^{15}$. This division of profit is meant as a form of compensation to the BLNS for the lack of a policy concerning educational tariffs, the aim of which is to protect selected sectors of the industry. Under the new agreement of 1994, all SACU states may introduce provisions concerning the development of common policy and establishment of common institutions. As regards common policy, the most important regulations are still the ones concerning the industry and competition as well as cooperation in agriculture.

Presently, the SACU is considered one of the most integrated economic communities in Africa. All of the SACU states are also members of the SADC and of the African Union, and Swaziland is additionally a member of the COMESA. This high number of integration agreements gives rise to conflicts of interest, as well as formal and financial problems. SACU is also one of the smallest groupings in Sub-Saharan Africa in terms of the number of members. The union also has in place a complementary document, the Multilateral Monetary Agreement, which has replaced the previous Common Monetary Area.

It is rather hard to classify the members of SACU as countries with a similar level of economic development, as there are considerable differences between them in terms of the structure of the economy, population, income per person, or level of technological advancement. Consequently, for the purpose of an analysis of multi-aspect indexes showing the level of development of states, the SACU states are classified in different groups. In the UN division based on the HDI, in 2013 Lesotho was in the group of countries with low HDI, while the other SACU members were in the group of countries with a medium HDI. The World Bank places South Africa, Botswana and Namibia in the group of upper middle income per person, while Lesotho and Swaziland are in the group of lower middle income ${ }^{16}$. The traits shared by the said countries are, in turn, considerable inequalities in income distribution, unemployment, inflation, as well as short life expectancy as compared to developed countries.

Against the background of other African organizations, SACU seems to be important economy, though it integrates a relatively small number of states and share of population in the world population. In terms of regional GDP, its share in world GDP, GDP per capita and its growth rates, and inward FDI flows, SACU seems to be relevant community in African society. SACU owes the relevant position in African economy to South Africa. Contrary to its strong economy, SACU achieves low indicators of intra-regional trade share in comparison to other analysed organizations, which indicates very low trade interdependence among members of SACU, but this indicator is determined mainly by South Africa. Certainly it is inferior to the largest economic blocks in Africa, such as Common Market for Eastern and Southern Africa 
(COMESA), Economic Community of West African States (ECOWAS), or Southern African Development Community (SADC) $)^{17}$. In terms of intra-regional trade intensity index SACU's intra-regional trade is largely less important than trade flows with the non-member states (it also the effect of South Africa) (Table 1).

Table 1. African communities: selected indicators in 2010

\begin{tabular}{|l|c|c|c|c|c|c|c|c|c|}
\hline \multicolumn{1}{|c|}{ Indicator } & IGAD & CEMAC & COMESA & EAC & ECCAS & ECOWAS & SACU & SADC & WAEMU \\
\hline $\begin{array}{l}\text { Intra-Regional Trade } \\
\text { Intensity Index }\end{array}$ & 102.83 & 178.72 & 9.70 & 136.04 & 193.59 & 6.66 & 4.39 & 13.50 & 5.81 \\
\hline $\begin{array}{l}\text { Intra-Regional Trade } \\
\text { Share }\end{array}$ & 8.21 & 7.05 & 6.00 & 11.00 & 8.85 & 4.32 & 3.13 & 12.15 & 3.75 \\
\hline $\begin{array}{l}\text { Regional GDP in current } \\
\text { prices (billion USD) }\end{array}$ & 160.37 & 76.15 & 551.30 & 79.14 & 179.20 & 37.21 & 396.32 & 565.04 & 260.33 \\
\hline $\begin{array}{l}\text { Regional GDP per } \\
\text { Capita }\end{array}$ & 743 & 1,763 & 1,144 & 580 & 1,216 & 1,027 & 6,859 & 2,174 & 1,090 \\
\hline $\begin{array}{l}\text { Regional GDP Share } \\
\text { in World GDP (\%) }\end{array}$ & 0.13 & 0.06 & 0.44 & 0.06 & 0.14 & 0.24 & 0.32 & 0.45 & 0.21 \\
\hline $\begin{array}{l}\text { Real GDP per capita } \\
\text { growth rates (\%) }\end{array}$ & 7.22 & 5.25 & 5.77 & 6.29 & 4.62 & 6.91 & 3.38 & 3.88 & 4.46 \\
\hline $\begin{array}{l}\text { Inward FDI flows } \\
\text { (millions USD) }\end{array}$ & 3,304 & 6,356 & 18,003 & 2,578 & 6,162 & 11,846 & 2,265 & 8,198 & 1,282 \\
\hline $\begin{array}{l}\text { Outward FDI flows } \\
\text { (millions USD) }\end{array}$ & n.a. & n.a. & 5,283 & n.a. & n.a. & 1,288 & -73 & 2,591 & -4 \\
\hline $\begin{array}{l}\text { Regional Population } \\
\text { (thousands of people) }\end{array}$ & 215,912 & 42,204 & $482,012.1$ & 136,532 & 147,424 & 299,069 & 57,780 & 259,896 & 238,826 \\
\hline $\begin{array}{l}\text { Regional Share in World } \\
\text { Population (\%) }\end{array}$ & 3.14 & 0.63 & 7.02 & 1.99 & 2.15 & 4.35 & 0.84 & 3.78 & 3.48 \\
\hline
\end{tabular}

Intra-Regional Trade Intensity Index is used to determine whether the value of intra-regional trade is greater or smaller than would be expected on the basis of the region's importance in world trade.

Source: author's own study on the basis of United Nations (2014), RIKS Platform (2014), The World Bank (2014).

\section{Changes in the foreign trade of the SACU countries}

The sphere that was to particularly contribute to boosting integration as well as social and economic development of the SACU countries was increasing the openness of the economy, benefiting from the effects of internationalisation and 'harnessing' globalisation ${ }^{18}$. While analysing the changes in the foreign trade channels of the SACU members, it is relevant not only to study the basic indexes of foreign exchange, but also to present the processes in which the trade structures of the countries in question are integrating, becoming similar or drifting apart. 
As a matter of fact, the share of SACU's foreign trade in global trade is not significant and has been subject to considerable fluctuations in the last decade. The members of the union are more active in terms of imports of goods (almost $0.8 \%$ of global imports in 2012) than in terms of exports (less than $0.6 \%$ of global exports). As regards foreign trade in services, the SACU countries play a marginal role in global trade, which is $0.37 \%$ of global exports of services and $0.47 \%$ of global imports of services. The share of SACU foreign trade in total African trade, however, points to an important position of the union in the region. In 2013, the share of the countries in question in African exports was $18.4 \%$, but it is a rather considerable decrease since 2000, when the union's exports constituted 23.7\% of total African exports. We can observe a similar trend in imports - the share of the SACU countries in Africa's imports fell from $27.1 \%$ in 2000 to $23.1 \%$ in 2013 . These decreases can be explained primarily by the increasing share in trade of the countries of Central Africa (e.g. Angola, Equatorial Guinea and the DRC) and of Western Africa (especially Nigeria) ${ }^{19}$.

When analysing the SACU trade exchange, it is hard not to notice the asymmetry of this exchange. Virtually the entire trade of the union is performed by South Africa. In 2013, SA had an $87 \%$ share in both the exports and imports of SACU. It is noteworthy that between 2000 and 2013, SA's share in SACU's trade turnover was around 90\%, with the other countries of the grouping having much smaller shares (Botswana having the largest share among them) ${ }^{20}$. It would be hard to question the fact that foreign trade within SACU has a prominent place in the trade of all the members of the union except for South Africa, which focused on the Chinese, American, Japanese and German markets. An analysis of the main export and import markets within the grouping shows that South Africa is undeniably the most important trade partner for the other signatories. It should be noted that there was a growth trend in the foreign trade of all SACU countries from 2000, which was disturbed in 2009 due to the global crisis ${ }^{21}$. Deteriorating terms of trade, as well as fall in trade turnover and income from foreign exchange were especially noticeable in the current account balances of the BLNS countries ${ }^{22}$.

While examining the level of concentration of the SACU countries' export markets, we can observe a decrease in the Herfindahl-Hirschman index in all countries except for Swaziland. The most significant decrease in the geographical concentration of exports was experienced by Lesotho, from which, in 2000, almost $72 \%$ of exports went to the USA. By 2009 , however, the structure of their main export partners shifted towards SA, where almost $49 \%$ of its exports went, with only $32 \%$ going to the USA. An opposite trend is observed in Swaziland, which is focusing more and more on the South African market. Among the SACU countries it is SA and Namibia 
that have the most diversified exports in geographical terms. An increasing diversification is observed import markets as well. Only Lesotho focused on importing goods from SA (Table 2).

Table 2. Index of export and import market concentration of the SACU countries in 2000 and 2012

\begin{tabular}{|l|c|c|c|c|}
\cline { 2 - 4 } \multicolumn{1}{c|}{} & \multicolumn{2}{c|}{ Export } & \multicolumn{2}{c|}{ Import } \\
\cline { 2 - 4 } \multicolumn{1}{c|}{} & 2000 & 2012 & 2000 & 2012 \\
\hline Botswana & 0.5133 & 0.3946 & 0.5490 & 0.4276 \\
\hline Lesotho* & 0.5919 & 0.3410 & 0.6397 & 0.9078 \\
\hline Namibia & 0.1917 & 0.0768 & 0.7442 & 0.4933 \\
\hline South Africa & 0.0522 & 0.0493 & 0.0627 & 0.0552 \\
\hline Swaziland** & 0.3720 & 0.6563 & 0.8681 & 0.6652 \\
\hline
\end{tabular}

*2009;**2007.

To calculate concentration index the author used HH index. The EU's market was analyzed as separated countries.

Source: author's own calculations on the basis of The World Bank (2014).

While analysing the synthetic measures of concentration of the commodity structure of exports and imports, we can observe that there is no clear trend. Generally, there is a very high concentration in terms of exports in all the SACU countries except for South Africa. In all the member countries, the share of the three largest commodity groups in the value of exports exceeds 50\%, reaching between $84 \%$ and $90 \%$ in Botswana, Lesotho and Swaziland. The Gini coefficient and the $\mathrm{HH}$ index, which are both close to 1 in these three countries, also point to high degree of commodity export concentration (Table 3). Botswana focuses on exports of gemstones and metals (diamonds, nickel and copper). Lesotho exports primarily textiles and clothing, but also wool and mohair, and food. Namibia focuses on exporting gemstones, minerals and metals (diamonds, copper, gold, zinc, uranium, lead), as well as food products (e.g. cattle, fish, molluscs). SA, in turn, exports mainly minerals, metals and gemstones (gold, diamonds, platinum) as well as, although to a lesser extent, machinery, electronics and transport equipment. Swaziland exports primarily chemical industry products (e.g. concentrates), food (e.g. sugar, fruit) and wood pulp. The country that managed to diversify the structure of its exports most significantly in 2000-2012 was Namibia. In Swaziland and SA we can observe an opposite trend. Swaziland focused more on exports of chemical industry products and food, while SA on exporting increasing amounts of gemstones, glass and minerals. The commodity concentration is much lower in imports, regardless of the indicator that is taken into account. SA and Botswana have the most concentrated imports. In SA, machinery and electronics, fuels and transport industry products constitute $57 \%$ of the value of imports. In Botswana, gemstones and glass, fuels and machinery and electronics comprise more than 58\% of imports (Table 3). 
The remaining countries have a more fragmented and diversified imports. It is worth noting that among the top commodities imported by every SACU country except for Lesotho are machinery and electronics ${ }^{23}$.

Table 3. Synthetic indicators of commodity trade concentration of the SACU states in 2000 and 2012

\begin{tabular}{|c|c|c|c|c|c|c|c|c|c|c|c|c|}
\hline & \multicolumn{6}{|c|}{ Export } & \multicolumn{6}{|c|}{ Import } \\
\hline & \multicolumn{2}{|c|}{ Gini coefficient } & \multicolumn{2}{|c|}{ HH index } & \multicolumn{2}{|c|}{$\begin{array}{l}\text { share of } 3 \text { most } \\
\text { important product } \\
\text { groups }(\%)\end{array}$} & \multicolumn{2}{|c|}{ Gini coefficient } & \multicolumn{2}{|c|}{ HH index } & \multicolumn{2}{|c|}{$\begin{array}{l}\text { share of } 3 \text { most } \\
\text { important product } \\
\text { groups }(\%)\end{array}$} \\
\hline & 2000 & 2012 & 2000 & 2012 & 2000 & 2012 & 2000 & 2012 & 2000 & 2012 & 2000 & 2012 \\
\hline Botswana & 0.917 & 0.901 & 0.694 & 0.661 & 91.3 & 89.7 & 0.412 & 0.5820 & 0.1030 & 0.1450 & 42.20 & 58.10 \\
\hline Lesotho* & 0.937 & 0.874 & 0.620 & 0.461 & 94.2 & 84.4 & 0.448 & 0.3020 & 0.1020 & 0.0830 & 43.30 & 34.10 \\
\hline Namibia & 0.731 & 0.663 & 0.234 & 0.163 & 71.3 & 63.7 & 0.453 & 0.4270 & 0.1070 & 0.0960 & 46.20 & 42.70 \\
\hline South Africa & 0.458 & 0.567 & 0.101 & 0.124 & 43.1 & 49.8 & 0.596 & 0.5960 & 0.1470 & 0.1450 & 56.70 & 57.00 \\
\hline Swaziland** & 0.717 & 0.832 & 0.18 & 0.341 & 67.5 & 84.1 & 0.419 & 0.4034 & 0.0952 & 0.0898 & 40.61 & 37.80 \\
\hline
\end{tabular}

*2009;**2007.

Source: author's own calculations on the basis of United Nations (2014), The World Bank (2014).

The commodity structure of the exports of the SACU countries is related to specialisation in international exports. In order to express the relative comparative advantage of a given commodity group in exports, it is most appropriate to calculate the international specialisation index. For this purpose, we have used the revealed comparative advantage index ${ }^{24}$. Generally, the SACU states export primarily those products in which they have comparative advantage. All these countries, except for Botswana, have an advantage in exports of food products. Minerals, gemstones and glass are also competitive products, especially for Botswana, Namibia and South Africa. Lesotho specialises in different sectors, except for food, and has a competitive advantage in footwear, textiles and clothing and vegetables. None of these countries have comparative advantage in more technologically advanced commodity groups, such as machinery and electronics or transport industry products (Table 4).

The diversity of the revealed comparative advantages is also reflected in the degree of similarity between the foreign trade commodity structures of the SACU states. In this study, the foreign trade commodity structure of SA has been adopted as the model, as it has been deemed the most advanced. In the analysis of the degree of similarity between the structures of commodities exported by the BLNS states and the export commodity structure, this study has used the Euclidean metric. Comparing the years 2000 and 2012, it can be observed that the structures of commodities exported by Botswana and Lesotho are gradually becoming more similar to the South African model. Namibia, on the other hand, drifted very clearly away 
Table 4. Revealed comparative advantage indexes of the SACU countries in 2000 and 2012

\begin{tabular}{|l|r|r|r|r|r|r|r|c|c|c|}
\cline { 2 - 11 } \multicolumn{1}{c|}{} & \multicolumn{2}{c|}{ Botswana } & \multicolumn{2}{c|}{ Lesotho } & \multicolumn{2}{c|}{ Namibia } & \multicolumn{2}{c|}{ South Africa } & \multicolumn{2}{c|}{ Swaziland } \\
\cline { 2 - 12 } \multicolumn{1}{c|}{} & \multicolumn{1}{c|}{2000} & \multicolumn{1}{c|}{2000} & 2012 & \multicolumn{1}{c|}{2000} & 2012 & 2000 & 2012 & 2000 & 2012 \\
\hline Animals & 0.984 & 0.622 & 0.537 & 0.052 & 10.763 & $\mathbf{9 . 6 6 5}$ & 0.716 & 0.405 & 1.042 & 0.113 \\
\hline Chemicals & 0.123 & 0.110 & 0.038 & 0.020 & 0.068 & 0.271 & 0.950 & 0.666 & 2.737 & 6.358 \\
\hline Food products & 0.258 & 0.211 & 1.195 & $\mathbf{1 . 7 5 4}$ & 2.727 & $\mathbf{2 . 1 4 1}$ & 1.588 & $\mathbf{1 . 0 1 6}$ & 11.022 & $\mathbf{7 . 5 4 1}$ \\
\hline Footwear & 0.118 & 0.039 & 10.224 & $\mathbf{6 . 2 5 0}$ & 0.129 & 0.078 & 0.141 & 0.091 & 0.024 & 0.014 \\
\hline Fuels & 0.008 & 0.037 & 0.000 & 0.002 & 0.213 & 0.059 & 1.048 & 0.735 & 0.073 & 0.101 \\
\hline Hides and skins & 0.410 & 0.200 & 0.051 & 0.000 & 1.423 & 0.923 & 1.167 & 0.508 & 0.218 & 0.100 \\
\hline Machinery and electronics & 0.048 & 0.091 & 0.254 & 0.498 & 0.067 & 0.175 & 0.293 & 0.375 & 0.272 & 0.126 \\
\hline Metals & 0.997 & 0.918 & 0.008 & 0.003 & 0.266 & $\mathbf{1 . 3 9 5}$ & 2.742 & $\mathbf{1 . 8 0 2}$ & 0.111 & 0.088 \\
\hline Minerale & 0.409 & $\mathbf{1 . 2 6 3}$ & 0.000 & 0.094 & 14.894 & $\mathbf{1 1 . 9 6 1}$ & 7.121 & $\mathbf{9 . 8 5 5}$ & 0.515 & 0.009 \\
\hline Plastics or rubber & 0.076 & 0.131 & 0.000 & 0.005 & 0.185 & 0.187 & 0.468 & 0.439 & 0.104 & 0.364 \\
\hline Stone and glass & 28.515 & $\mathbf{1 8 . 2 3 2}$ & 0.103 & 0.625 & 14.093 & $\mathbf{6 . 2 1 2}$ & 3.017 & $\mathbf{4 . 9 5 7}$ & 0.076 & 0.112 \\
\hline Textiles and clothing & 0.296 & 0.328 & 13.485 & $\mathbf{1 4 . 9 7 5}$ & 0.092 & 0.114 & 0.418 & 0.210 & 3.114 & $\mathbf{1 . 0 6 2}$ \\
\hline Transportation & 0.186 & 0.226 & 0.000 & 0.007 & 0.101 & 0.711 & 0.745 & 0.986 & 0.125 & 0.063 \\
\hline Vegetables & 0.099 & 0.088 & 0.310 & $\mathbf{1 . 1 2 7}$ & 0.500 & 0.362 & 1.397 & $\mathbf{1 . 2 8 9}$ & 1.112 & 0.697 \\
\hline Wood & 0.102 & 0.121 & 0.009 & 0.258 & 2.446 & 0.404 & 1.372 & 0.879 & 3.324 & $\mathbf{3 . 8 6 1}$ \\
\hline Miscellaneous & 0.041 & 0.034 & 0.012 & 0.368 & 0.182 & 0.185 & 1.665 & 0.158 & 0.412 & $\mathbf{0 . 1 2 8}$ \\
\hline
\end{tabular}

The value more than one means revealed comparative advantage.

Source: author's own calculations on the basis of OECD-WTO.

from the model in terms of the structure of exports. Generally speaking, the relatively high values of the indicators describing similarity of export structures mean that the structures of exported commodities deviate significantly from the South African model. As for the similarity of imports, we can observe small values of the Euclidean metric, which implies a considerable similarity of the import structures of the examined countries to the South African model. Among these countries, Namibia is characterised by highest similarity to the South African model and Botswana the lowest similarity. Furthermore, in the analysed period, Botswana experienced the greatest decrease in similarity between its import structure and the South African model (Figure 1).

The low share of products considered the most technologically advanced is a disadvantageous characteristic of the export of the SACU countries. On the other hand, it is still under discussion whether the export of high-tech products in developing countries is tantamount to actual technological development ${ }^{25}$. These doubts are usually justified by the statement that technologically advanced exports do not necessarily have to be the result of actual innovative activity of countries, but rather of a suitable position in global value chains based on revealed comparative advantages (vertical specialisation) ${ }^{26}$. We can attempt to explain the low technological advancement of the SACU countries by its very low share of expenses on research and development. As regards the share of high-tech product exports in the total 

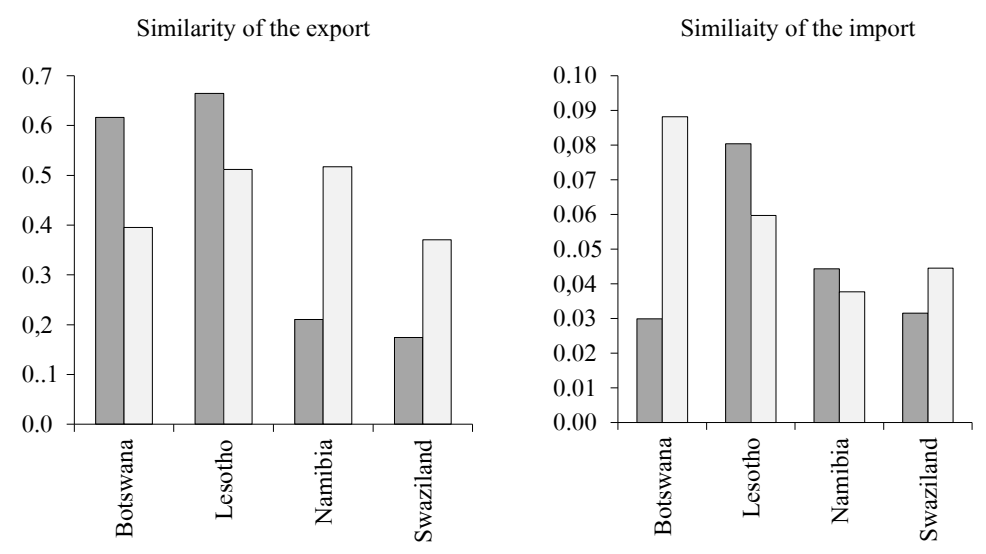

$\square 2000 \square 2012$

Euclidean metric has been used as the measure of similarity. The closer the value is to one, the more different are the export structures of the analysed countries. The closer the value is to zero, the more similar the commodity structures.

Fig. 1. Similarity of the trade commodity structure of the SACU states in 2000 and 2012 Source: author's own calculations on the basis of The World Bank (2014).

value of industrial product exports, in 2012 it was the highest for Swaziland (more than 40\%). However, the country's high percentage of high-tech exports is primarily the result of the low scale of its overall exports of industrial products and does not point to Swaziland's technological advancement, as proven by, for instance, the innovation indexes ${ }^{27}$. Swaziland's high-tech exports are based on foreign investments connected with mining technologies and the construction of cooling devices. In terms of value, in 2012 Swaziland's high-tech sector constituted 5\% of the value of high-tech exports of South Africa. The high-tech export of Namibia seems large as well and is partially the result of the National Research, Science and Technology Policy introduced by the government in $1999^{28}$. Nonetheless, the main reason behind it is - just as in Swaziland - foreign investments. SA is the most advanced SACU country in terms of technology, even though the high-tech exports of this country in 2012 constituted only $24.2 \%$ of the value of industrial products. SA specialises chiefly in exports of telecommunications equipment, pharmaceutical and medical products, electronic equipment and products based on the phenomenon of thermionic emission and photocathode. In 2012, SA was responsible for more than $90 \%$ of total high-tech exports of the SACU countries, while Swaziland accounted for only $4.3 \%$. Among these countries, Lesotho has the lowest level of technological advancement among exported products, as almost its entire exports are based on labour-intensive products (textiles, clothing, footwear) ${ }^{29}$. 


\section{The SACU states' role in GVCs: the case of South Africa ${ }^{30}$}

The countries of Southern Africa still participate in GVCs only to a small extent ${ }^{31}$. However, the omnipresent delocalisation and fragmentation of production have not left this region unaffected. As the most economically advanced country of the region, SA joined the GVCs the soonest. Transformations in the South African economy resulted in foreign enterprises deciding to take advantage of the country's comparative advantages ${ }^{32}$. Thanks to its factors of production and level of development, which makes it stand out amongst the other African states, SA is attractive for four types of investors, looking for four things: resources, a ready market, a reduction of production costs, and strategic assets (e.g. regarding the power industry, railroad network $)^{33}$. Even though, in comparison to the most developed states, workforce productivity in South Africa is much lower ${ }^{34}$, the wages per hour are also much lower than the average set by developed countries ${ }^{35}$. The cost factor, diversified economy, development strategies that put stress on innovative sectors of the economy, lower risk of conducting business and a relatively well developed infrastructure compared to other countries of Sub-Saharan Africa, as well as very advanced liberalisation, have resulted in increased interest among foreign investors in investing their capital in SA. They are mainly interested in investing in oil and gas extraction, as well as coal and metal mining, followed by investments in the automotive industry, the energy industry and communication. In 2012, accumulated foreign investments in South Africa constituted more than $95 \%$ of the FDI in the entire SACU and more than $22 \%$ of investments in Africa's developing countries ${ }^{36}$. In 2003-2011, new FDI projects increased by $321 \%$ and generated more than 41.5 thousand new jobs. In 2007-2011, FDI inflow to SA was growing on average by $24.7 \%$ per year. According to the studies conducted by Oxford Economics and Ernst \& Young Africa, the top factors that attract investors to SA include: mineral resources, market size, relatively low corruption and political stability in comparison to the other African countries $^{37}$.

Leaving aside the influence of the redistribution of income between countries with different levels of development, which has already been discussed on numerous occasions in academic literature on the results of globalisation, the introduction of international fragmentation of production has made it possible to boost selected branches of South Africa's economy in which there already had been comparative advantage or at least a fair chance for increasing international competitiveness. Therefore, it is an attractive development strategy for SA to participate in GVCs. It should be noted that there are severe methodological difficulties with determining the place of a given country in value networks. One of the reasons for these problems is the lack 
of a unified method of measuring value added and the lack of the latest data concerning the flow of value added in international exchange, especially as regards the developing countries. When attempting to determine the place of SA in GVCs, we should analyse its values added in trade. The first symptom indicating that a country has joined the GVCs can be the decrease in the share of domestic value added in gross exports. This automatically implies an increase in foreign value added and a stronger link with the GVCs. For SA, it is hard to present a uniform trend in this respect. Indeed, between 1995 and 2008, the share of foreign value added in South Africa's gross exports grew, but in 2009 this trend came to a halt, probably due to bad overall global economic situation ${ }^{38}$. The actual changes in South Africa's value added in exports should be examined in relation to the individual sectors of the economy or commodity groups. Between 1995 and 2009, the greatest decrease in the share of domestic value added was observed in transport equipment, metal products and machines and equipment, as well as electrical and optical equipment. Only the mining and quarrying and financial brokerage increased the share of value added in gross exports. A good example of participation in GVCs are the metallurgical and transportation sectors. An analysis of the FDI channels flowing into SA in these two sectors shows that, by 2012, these two sectors received respectively $20 \%$ and $9 \%$ FDI. This proves a strong internationalisation of these sectors and their integration with global production, which is reflected in the analysis of the share of domestic value added - in both sectors, between 2000 and 2009 the share of domestic value added in gross exports clearly decreased (Table 5). However, this highly simplified analysis does not solve the problem of determining the position of the country in GVCs.

When we examine the share of foreign value added included in the products exported by South Africa, we can see that the dominating element is the value added from highly developed countries. The share of value added from OECD countries in South Africa's gross exports in 2009 was as much as 53\%. The countries characterised by the highest share of value added in the products sold by SA abroad are as follows: the USA (10\%), Saudi Arabia (9.7\%), Germany (9.1\%), and China (5.3\%). In its exports, SA benefits primarily from foreign value added from transport equipment (38\% of gross exports of this commodity group), electronics and optics $(27 \%)$, the metallurgical industry (27\%), as well as chemical products $(22 \%)$. In 2009 , the most value added from SA in foreign exports could be found in European exports (approximately $36.3 \%$ of total South African value added embodied in foreign exports ${ }^{39}$ ), of which value added from SA constituted $30.9 \%$ in EU-27 gross exports. The most important EU countries benefiting from South African value added in 2009 were Germany and France. In the year in question, more than $16.2 \%$ of the total value added of SA embodied in foreign exports was generated 
by Southeast Asia and $12.2 \%$ by East Asia. The major commodity groups in which foreign countries use value added from SA are as follows: chemical industry products, machinery and equipment (mainly transport equipment), transport, storage and business sector services ${ }^{40}$.

Table 5. Percentage share of domestic and foreign value added in South African gross exports in individual sectors in 1995, 2000, and 2009

\begin{tabular}{|l|r|r|r|r|r|r|}
\cline { 2 - 7 } \multicolumn{1}{c|}{} & \multicolumn{2}{|c|}{1995} & \multicolumn{2}{c|}{2000} & \multicolumn{2}{c|}{2009} \\
\cline { 2 - 7 } \multicolumn{1}{c|}{} & DVA & FVA & DVA & FVA & DVA & FVA \\
\hline Total & 88.25 & 11.75 & 83.86 & 16.14 & 83.51 & 16.49 \\
\hline Agriculture, hunting, forestry and fishing & 91.00 & 9.00 & 87.23 & 12.77 & 86.37 & 13.63 \\
\hline Mining and quarrying & 89.30 & 10.70 & 86.89 & 13.11 & 89.73 & 10.27 \\
\hline Food products, beverages and tobacco & 89.55 & 10.45 & 87.38 & 12.62 & 85.31 & 14.69 \\
\hline Textiles, textile products, leather and footwear & 83.9 & 16.10 & 81.83 & 18.17 & 81.95 & 18.05 \\
\hline Wood, paper, paper products, printing and publishing & 85.63 & 14.37 & 83.41 & 16.59 & 81.96 & 18.04 \\
\hline Chemicals and non-metallic mineral products & 83.01 & 16.99 & 78.82 & 21.18 & 78.04 & 21.96 \\
\hline Basic metals and fabricated metal products & 86.33 & 13.67 & 80.27 & 19.73 & 73.25 & 26.75 \\
\hline Machinery and equipment & 83.68 & 16.32 & 78.61 & 21.39 & - & - \\
\hline Electrical and optical equipment & 83.76 & 16.24 & 77.86 & 22.14 & 73.27 & 26.73 \\
\hline Transport equipment & 78.12 & 21.88 & 64.13 & 35.87 & 61.58 & 38.42 \\
\hline Manufacturing & 88.87 & 11.13 & 77.51 & 22.49 & 81.23 & 18.77 \\
\hline Electricity, gas and water supply & 95.54 & 4.46 & 93.89 & 6.11 & 91.71 & 8.29 \\
\hline Construction & 87.89 & 12.11 & 84.53 & 15.47 & 82.96 & 17.04 \\
\hline Wholesale and retail trade; Hotels and restaurants & 94.18 & 5.82 & 94.02 & 5.98 & 91.91 & 8.09 \\
\hline Transport and storage, post and telecommunication & 93.49 & 6.51 & 91.70 & 8.30 & 86.89 & 13.11 \\
\hline Financial intermediation & 95.31 & 4.69 & 95.96 & 4.04 & 95.92 & 4.08 \\
\hline Business services & 92.96 & 7.04 & 92.67 & 7.33 & 90.43 & 9.57 \\
\hline Other services & 92.79 & 7.21 & 92.11 & 7.89 & 88.48 & 11.52 \\
\hline
\end{tabular}

DVA - domestic value added; FVA - foreign value added.

Source: author's own study on the basis of TiVA OECD-WTO.

An important indication of participation in GVCs is the share of imports used (directly and indirectly) for the current production of goods and services for export (so-called re-exported intermediates), as it provides us with the information on the position of countries in GVCs. Imported intermediate goods directly connected with exports constitute more than $27 \%$ of exports in South Africa. This percentage is quite significant compared with the USA, Australia or Japan (approximately 20\%), but it is still far below the values achieved by Luxembourg, Singapore or Taiwan (approximately 70-80\%), which are largely based on imported parts, which are then assembled and exported as final products. Between 2000 and 2009, South Africa's reexported intermediates decreased from more than 32\%, which implies an improvement of the country's position in the level of advancement of production as compared to $2000^{41}$. 
A more complex method of measuring South Africa's participation in GVCs is a decomposition of the value added in gross exports followed by determining foreign value added in total gross domestic exports and domestic value added in the exports of the trade partners of the analysed country. Adopted methodology founds on approach elaborated by the researchers from the NBER ${ }^{42}$. These indicators describe the position of the state in downstream and upstream relations in GVCs. Due to length imitation of the publication, mentioned below analysis presents only the results of calculations.

The analysis of the decomposition of value added includes, apart from SA, also the EU27, Germany, Poland, the USA, Japan, and China, as important links in GVCs. The results of the study show that the shares of foreign value added contained in domestic exports of the analysed states are very diverse. Between 2000 and 2009 the share of foreign value added in SA's exports remained almost without change. However, compared to the EU-27, the USA and Japan this value is still high ${ }^{43}$. A negative trend is observed in the share of domestic value added contained in exports of SA's trade partners. In 2000-2009, it decreased from 32\% to $17.3 \%$. This value is much lower than what was achieved by developed countries and signifies a decreasing role of the country as the supplier of value added to the global markets. We can also observe a decrease in the level of South Africa's participation in GVCs, which is an exception among the analysed countries. As a matter of fact, the results of the study show bidirectional links of the analysed country in vertical specialisation, although with a stronger tendency to hold lower positions in GVCs than developed countries, especially in the more technologically advanced sectors of the economy. The greater prominence of downstream relations is proven by the indicator of the relative position in GVCs. The higher the value of the indicator, the higher the country's position within GVCs (upstream segment). The borderline value between segments is 1. As a result, South Africa was positioned lower in GVCs than the USA and Japan and even the EU average. The indicator of South Africa's relative position in GVCs was 1.05, that is at the borderline between the upstream and downstream segments. It is an alarming fact that SA's position in GVCs has been rapidly deteriorating in the recent years. In 2000, it was still clearly in the upstream segment, higher than e.g. the EU average. This indicates that South Africa's role as a link in the chain of production of the global economy is decreasing (Table 6).

We could also try to identify the position of SA depending on the place it occupies in each sector. Four most internationalised braches have been selected for this analysis: transport equipment, electrical and optical equipment, mining and metallurgical industry. The first two can be considered more technologically advanced, while the remaining ones are considered less advanced. In the production of transport equipment, electrical and optical equipment SA 
Table 6. The degree of participation of selected countries in GVCs in 2000 and 2009 (\%)

\begin{tabular}{|l|c|c|c|c|c|c|c|c|c|}
\cline { 2 - 10 } & \multicolumn{2}{c|}{$\begin{array}{c}\text { VA from trade part- } \\
\text { ners embodied in } \\
\text { country total exports } \\
\text { (in \% of country } \\
\text { total exports) }\end{array}$} & $\begin{array}{c}\text { VA from country } \\
\text { embodied in trade } \\
\text { partners total exports } \\
\text { (in \% of country } \\
\text { total exports) }\end{array}$ & $\begin{array}{c}\text { Degree of participa- } \\
\text { tion in GVCs } \\
\text { (in \% of country } \\
\text { total exports) }\end{array}$ & $\begin{array}{c}\text { Importance of partici- } \\
\text { pation in GVCs } \\
\text { for the national } \\
\text { economy (in \% } \\
\text { of country GDP) }\end{array}$ & $\begin{array}{c}\text { Relative } \\
\text { position } \\
\text { in GVC* }\end{array}$ \\
\cline { 2 - 12 } & 2000 & 2009 & 2000 & 2009 & 2000 & 2009 & 2009 & 2000 & 2009 \\
\hline SA & 16.14 & 16.49 & 32.0 & 17.3 & 48.14 & 34.39 & 8.82 & 1.98 & 1.05 \\
\hline UE-27 & 12.63 & 13.62 & 18.0 & 17.8 & 30.63 & 31.42 & 4.29 & 1.43 & 1.31 \\
\hline Phina & 18.81 & 32.63 & 13.8 & 13.4 & 32.61 & 46.03 & 11.84 & 0.73 & 0.41 \\
\hline Germand & 23.33 & 27.89 & 24.1 & 20.5 & 47.43 & 48.39 & 10.84 & 1.03 & 0.74 \\
\hline US & 24.40 & 26.64 & 24.4 & 22.8 & 48.80 & 49.44 & 17.34 & 1.00 & 0.86 \\
\hline Japan & 8.88 & 11.29 & 31.1 & 28.5 & 39.98 & 39.79 & 4.02 & 3.50 & 2.52 \\
\hline
\end{tabular}

* The higher the value of the index, the more upstream the country exporters are situated in GVCs.

Calculations on the basis of participation indices (forward and backward).

Source: author's own calculations on the basis of TiVA OECD-WTO.

Table 7. South Africa and other countries in selected industries' GVCs (data of 2009)

\begin{tabular}{|c|c|c|c|c|}
\hline & Transport equipment & $\begin{array}{c}\text { Electrical and optical } \\
\text { equipment }\end{array}$ & Mining and quarrying & $\begin{array}{c}\text { Basic metals and fabricated } \\
\text { metal products }\end{array}$ \\
\hline 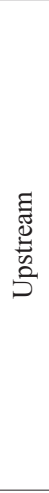 & $\begin{array}{l}\text { Japan (14.05) } \\
\text { USA (5.95) } \\
\text { Czech Republic (5.64) } \\
\text { Romania (3.90) } \\
\text { Hungary (3.76) } \\
\text { Germany (3.65) } \\
\text { South Korea (3.42) } \\
\text { Slovakia (3.08) } \\
\text { Poland (2.82) } \\
\text { Italy (2.73) } \\
\ldots \ldots \ldots . . .\end{array}$ & $\begin{array}{l}\text { Taiwan }(21.31) \\
\ldots \ldots \ldots . . \\
\text { Singapore }(19.93) \\
\text { South Korea }(12.68) \\
\ldots \ldots \ldots . . \\
\text { Japan }(5.78) \\
\ldots \ldots \ldots . . \\
\text { China }(4.74) \\
\ldots \ldots \ldots . . \\
\text { Germany }(1.95) \\
\ldots \ldots \ldots . . \\
\text { Poland }(1.26) \\
\ldots \ldots \ldots . . . \\
\text { India }(1.14) \\
\end{array}$ & $\begin{array}{l}\text { Saudi Arabia (5914) } \\
\text { Russia Federation (369) } \\
\text { Chile (366) } \\
\text { Norway (345) } \\
\ldots \ldots \ldots . . . \\
\text { Australia (148) } \\
\text { Canada (80) } \\
\text { South Africa (76) } \\
\ldots \ldots \ldots . . . \\
\text { India (31) } \\
\ldots \ldots . . . . .\end{array}$ & $\begin{array}{l}\text { Russia Federation (47.0) } \\
\text { Brazil (29.8) } \\
\text { Japan }(20.2) \\
\text { Australia (13.2) } \\
\text { USA }(13.0) \\
\ldots \ldots \ldots . \\
\text { South Africa (9.6) } \\
\ldots \ldots \ldots . . \\
\text { Poland (7.4) } \\
\ldots \ldots \ldots . . \\
\text { Germany (6.9) } \\
\text {......... } \\
\text { China (4.1) } \\
\text {......... }\end{array}$ \\
\hline 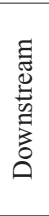 & $\begin{array}{l}\text { china }(0.91) \\
\ldots \ldots \ldots \\
\text { South Africa }(\mathbf{0 . 2 8}) \\
\text { New Zealand }(0.25) \\
\ldots \ldots \ldots\end{array}$ & $\begin{array}{l}\ldots \ldots . . . \\
\text { Russia Federation }(0.48) \\
\ldots \ldots \ldots . . \\
\text { South Africa }(\mathbf{0 . 2 2}) \\
\ldots \ldots \ldots . . \\
\text { Australia }(0.179)\end{array}$ & $\begin{array}{l}\text { South Korea }(0.88) \\
\text { France }(0.73) \\
\ldots \ldots \ldots . . . \\
\text { Ireland }(0.13) \\
\ldots \ldots \ldots . .\end{array}$ & $\begin{array}{l}\text { Philippines }(0.8) \\
\text { Singapore }(0.7) \\
\ldots \ldots \ldots . . \\
\text { Saudi Arabia }(0.2) \\
\end{array}$ \\
\hline
\end{tabular}

The industrial value chains are based on the relative position in GVCs in analyzed industry.

Source: author's own calculations on the basis of TiVA OECD-WTO. 
is clearly in the downstream segment. The automotive industry is the domain of developed countries, including the countries of Central and Eastern Europe, which are in the lead of the supply network. In the last years, it has become the driving force behind exports and has attracted considerable foreign investments to these countries. The transport industry in SA does not have such a long tradition, as a result of which the country is positioned low in GVCs ${ }^{44}$. The commodity group of electrical and optical equipment, in turn, has traditionally been the domain of the Asian Tigers and many years will pass before the South African economy achieves a comparable level of technological advancement. The mining and metallurgical industries position SA in the upstream segment and at a rather high place at that. As a matter of fact, South Africa is still perceived by foreign countries more often as a country of natural resources than advanced technologies, hence this high position in GVCs (Table 7).

\section{Conslusions}

It is the priority of the African countries of SACU to reduce the development gap between them and the developed countries. One of the means to achieve this goal is to ensure proper management of foreign trade and gradually join the global economy. However, the members of SACU are very diverse in terms of the level of economic, social and institutional development, and there are also considerable differences in the orientation of their foreign policies, which translates into trade flows. The union, dominated by South Africa, largely realises the goals of this country, thus causing even greater economic polarisation of the other members. Being a signatory of many international agreements, e.g. with the EU, SA is not interested in helping sign such agreements within SACU. Generally, the accelerating spread of global value networks put SACU states, except for South Africa, at a disadvantage in the competition for GVC investments. South Africa's policy that aims at benefitting from global value chains has not spread over whole union. Therefore the rest of the SACU members must effectively address their shortcomings, especially in infrastructure and labor skills, the environment given to domestic and foreign investors, and effective openness to trade.

The analysis yields the following conclusions: first, close integration of the countries of Southern Africa within SACU does not translate into increasing similarity of the geographical and commodity structure of international trade; second, the union is still dominated by SA, which benefits the most from trade flows within SACU (it is the main partner of the BLNS countries). Third, the trade policy of SA favours greater integration with global economies than with the SACU countries. Fourth, the study of the position of the most developed SACU country 
- SA - in GVCs shows that the region is still perceived as a supplier of low-processed products and resources rather than medium-tech and high-tech production. South Africa's position in GVCs further points to the possible directions of the economic policy that should be taken by the SACU states if they want to rise in the value network.

\section{Acknowledgments}

The article is the result of the research project "Theoretical, institutional and empirical conditions and premises of economic potentials synergies of African countries and Polish economy" financed by the National Science Centre, Poland (decision no. DEC-2012/07/B/ HS4/00743).

\section{Notes}

1 Zwoliński (2009).

${ }^{2}$ Latoszek (2010).

3 Wague (2010).

${ }^{4}$ Lizak, Milewski (2002).

${ }^{5}$ Czerniachowski et al. (2012).

${ }^{6}$ Liberska (2013); Żukrowska (2012).

7 Skidmore-Hess, Skidmore-Hess (2013).

${ }^{8}$ Salami (2012).

${ }^{9}$ McCarthy (2006).

${ }^{10}$ Erasmus (2014), pp. 211-216.

11 SACU (2014).

${ }^{12}$ Baldwin (1994).

13 SACU (2014).

${ }^{14}$ In 2012-2013, South Africa's share in the income of SACU was estimated at more than 45\%, Botswana's at $19.8 \%$, Namibia's at $17.8 \%$, Swaziland's at 9.6\%, and Lesotho's at 7.8\%. In 2011, South Africa's the share of customs tariffs and other taxes on imports in the total income from all taxes was 4.43\%. In Botswana, in turn, it was 34.25\% (The World Bank, 2014).

15 SACU (2013).

16 The World Bank (2014).

17 Though we should be cautious analyzing intra-regional trade shares, because organizations with a higher number of states and larger regions (in terms of total trade) tend to present a higher intra-regional trade share.

${ }^{18}$ Kwiecień-Rosińska (2012), pp. 151-174.

19 UNCTAD (2014)

${ }^{20}$ Ibidem.

${ }^{21}$ Chauvin, Geis (2011).

${ }^{22}$ IMF (2011)

${ }^{23}$ The World Bank (2014). 
24 Balassa (1965), pp. 99-123.

${ }^{25}$ Mani (2000); Srholec (2005).

${ }^{26}$ Dicken et al. (2011), pp. 89-112.

${ }^{27}$ In 2013, it had the 104th place among 142 countries in the Global Innovation Index, while SA was the highest: at the 58th place (World Economic Forum, 2013).

28 Matengu (1999).

29 UNCTAD (2014).

30 Some aspects of this section were discussed in (Cieślik 2014).

31 ADB, OECD, UNDP (2014).

${ }^{32}$ Martin (2013).

${ }_{33}$ Proksch (2003); Ernst and Young (2014).

${ }^{34}$ For example, in 2010 productivity in SA was less than $18 \%$ of the productivity in the USA, $22 \%$ of the productivity of the average employee in Germany, $67 \%$ of the productivity in Poland, $20 \%$ of the productivity in Australia, and $17 \%$ of the productivity of an average Japanese worker (The World Bank 2014).

${ }^{35}$ In 2010, the monthly minimum wage in SA was USD 463, while in the USA it was USD 1124, in Germany USD 1023, in Japan USD 1221, and in Australia USD 1158. It has also been estimated that by 2030 the average monthly wage in South Africa will increase to USD 3517, which will constitute $77 \%$ of the wages in the USA, Korea or Japan (ILO, 2012).

36 UNCTAD (2014).

37 Ernst, Young (2012).

38 OECD (2014).

39 Calculation excluding value added exported by South Africa itself.

${ }^{40}$ OECD (2014).

${ }^{41}$ Feenstra, Hanson (1999); OECD (2014).

42 Koopman et al. (2010).

${ }^{43}$ At this point, it is also worth looking closer into the situation of Germany. It has a relatively high percentage of foreign value added contained in exports, GVCs are of great significance in its national economy and the share of imports for current production in its exports is much higher than in other developed countries. The primary reason for this is the specific role played by Germany as a middleman in the trade of intermediate goods, mainly with the countries of Central and Eastern Europe. A particularly pronounced vertical integration between the post-socialist countries and Germany can be observed in more advanced products. These strong relations between the countries are the consequence of differences in labour costs and workforce qualifications, as well as of sectoral and cultural similarity and geographical proximity (IMF, 2013).

${ }^{4}$ Naude (2013).

\section{References}

ADB, OECD, UNDP. (2014). African Economic Outlook 2014. Global Value Chains and Africa's Industrialisation. ADB, OECD, UNDP.

Balassa, B. (1965). Trade Liberalisation and „Revealed” Comparative Advantage. The Manchester School of Economics, May.

Baldwin, R. (1994). Towards an Integrated Europe. Geneva: Graduate Institute of International Studies. 
Chauvin, S. \& Geis, A. (2011). Who Has Been Affected, How and Why? Frankfurt: European Central Bank.

Cieślik, E. (2014). Foreign trade and global value chains of the Southern African Customs Union's members. Economics and Management: Current Issues and Perspectives, 2 (34).

Czerniachowski, K., Kopiński, D. \& Polus, A. (2012). Klątwa surowcowa w Afryce? Warszawa: CeDeWu.

Dicken, P., Kelly, P. \& Olds, K. (2011). Chains and Networks, Territories and Scales: Towards a Relational Framework for Analysing the Global Economy. Global Networks, April.

Erasmus, G. (2014). Namibia and the Southern African Customs Union. In: Namibia's Foreign Relations, eds. A. Bösl, A. du Pisani, D. Zaire. Windhoek: Konrad Adenauer Foundation.

Ernst \& Young. (2012). Repositioning the South African Investment Case.

Ernst \& Young. (2014). Africa 2014. Executing Growth. EY.

Feenstra, R. \& Hanson, G. (1999). The Impact of Outsourcing and High-Technology Capital on Wages: Estimates for the United States, 1979-1990. The Quarterly Journal of Economics, 114 (3), 907-940.

ILO. (2012). Global Wage Report 2012-2013. Geneva: ILO.

IMF. (2011). In the Wake of the Global Economic Crisis: Adjusting to Lower Revenue of the Southern African Customs Union in Botswana, Lesotho, Namibia, and Swaziland. Washington, DC: IMF.

IMF. (2013). Trade Interconnections: The World with the Global Value Chains. Washington, DC: IMF.

Koopman, R., Powers, W., Wang, Z. \& Wei, S.-J. (2010). Give Credit Where Credit Is Due: Tracing Value Added in Global Production Chains. NBER Working paper 16426.

Kwiecień-Rosińska, J. (2012). Ujarzmianie globalizacji w Afryce. In: Harnessing globalization czyli ujarzmianie globalizacji, ed. K. Żukrowska. Warszawa: Oficyna Wydawnicza SGH.

Latoszek, E. (2010). Pomoc rozwojowa dla krajów rozwijajacych się na przełomie XX i XXI wieku. Warszawa: Oficyna Wydawnicza SGH.

Liberska, B. (2013). Nowe centra wzrostu światowej gospodarki. Studia Ekonomiczne, LLXXVII (2), 191-212.

Lizak, W. \& Milewski, J. (2002). Stosunki międzynarodowe w Afryce. Warszawa: Scholar.

Mani, S. (2000). Exports of High-Technologu Products from Developing Countries: Is Real or a Statistical Artefact? UNU/INTECH Discussuin Papers.

Martin, W.G. (2013). South Africa and the World Economy: Remaking Race, State, and Region. University of Rochester. 
Matengu, K. (2011). Successful Technology and Innovation Policy for Namibia: A Review of Issues and Lessons for a Developing Country. Technology Manaement in the Energy Smart World, 1-5.

McCarthy, C. (2006). The Southern African Customs Union - A Review of Critical Elements in the Development of the World's Oldest Customs Union. Journal of Law and Economics in International Trade, 2.

Naude, M.J. (2013). Supply chain challenges in the South African automotive sector: Do location, size and age matter? South African Journal of Economic and Management Sciences, $16,407-417$.

OECD (2014). OECD.StatExtracts, http://stats.oecd.org (29.04.2014).

Proksch, M. (2003). Selected Issues on Promotion and Attraction of Foreign Direct Investment in the Least Developed Countries and Economies in Transition. Investment Promotion and Enterprise Development Bulletin for Asia and the Pacific No 2, UN, 1-18.

RIKS Platform (2014). RIKS Database.

SACU. (2013). Annual Report 2012. Windhoek.

SACU. (2014). SACU, www.sacu.int (9.05.2014).

Salami, I. (2012). Financial Regulation in Africa: An Assessment of Financial Integration Arrangements in African Emerging and Frontier. University of East London: Ashgate Publishing.

Skidmore-Hess, D. \& Skidmore-Hess, C. (2013). Evaluating SADC and NAFTA as Regional Development Models. International Social Science Review, 88 (1-2).

Srholec, M. (2005). High-Tech Exports from Developing Countries: A Symptom of Technology Spurts or Statistical Illusion. TIK Working Papers (University of Oslo).

The World Bank. (2014). The World Bank Open Data, http://data.worldbank.org (28.05.2014).

The World Bank. (2014). World Integrated Trade Solution, http://wits.worldbank.org/Default. aspx (29.04.2014).

UNCTAD. (2014). UNCTAD Statistics, http://unctad.org/en/Pages/Statistics.aspx (27.05.2014).

United Nations. (2014). UN Comtrade, http://comtrade.un.org (29.04.2014).

Wague, M. (2010). Problemy rozwoju gospodarki rolnej w Afryce i czynniki ją ograniczające. Zeszyty Naukowe SGGW-Ekonomika i Organizacja Gospodarki Żywnościowej, 85, 135145.

World Economic Forum (2013). The Global Competitiveness. Geneva: WEF.

Zwoliński, A. (2009). Biedy Afryki. Kraków: Pertus.

Żukrowska, K. (2012). Rozwój w Afryce - rola rynków wschodzących. In: Afryka: o godność życia, ed. K. Kłosiński. Lublin: Wydawnictwo KUL. 